\section{$\diamond$ 北海道部会}

日時 昭和 50 年 6 月 $7 ， 8$ 日

会場 札帵医科大学大講堂

シンポジゥム「被検者の被曝軽減（性腺直接部位）」

1.「性腺直接部位」の被曝線量 軽減について（基礎的 考察)

笑唄労災病院 福田儀三郎

医療に項献しているX線も障珸作用を有し，近年，特 に医療被曝について一般の関心が高まっていることは周 知の事実である。 そとで直接性腺が被曝される部位より 小昌股関節, 成人股関節, 胎览撮影を選び如何に被曝線 量を軽減出来るか基礎的な検詩をした，又，北海道の掫 影の現状の概略を知るため道内 100 ケ所の病院をランダ ムに選び発生装瞋, 増感紙, フィルム, 現像法, 再撮影 の件数及び理由, 小韭股関節, 成人股関節, 胎児, 泌厡 器系統の撮影条件, 防護具の使用状沅, 防護具の形状, 鉛当量, 附加フィルタ一等についてアンケート調查を行 なった。

当施設に於て，上記部位中より鼠も多い小児股関微撮 影について特に検討を加えて見た結果，被曝線量軽減に は，

・防護具の使用と照射野を限界迄制限する。

・高感度増感紙, 高感度フィルムの使用.

・電圧をなるべく高くし附加フィルターを用いる。

以上の併用がより效果的であることが雨確弪出来た。

\section{2. 泌尿器科系撮影における被曝の軽減について}

市立釧路総合病院放射線科

○大久保定男・表 富司男 $\cdot$ 小野常美

富武敏境・坂上雅俊

[目的]

泌尿器科系撮影における, 生殖腺線量値の把握之, 軽 減について検討した。

[应法]

水ファントームを使用し，生殖腺および皮膚表面に相 当する部位に小型電離箱を扔き, 利用線錐内の埸合之, 線錐外の各距離における，被曝線量を測定した。各種増 感紙，フィルムの感度比較，および管電庄特性. 結石に 関する情報量. 鮮鋭度比軷. 以上について，一般的管電 在撮影法之, 高電王撮影法について, 各々に検討を加え た。

[結果]

高電王撮影法では，それぞれの堌感紙レベルで, 被曝 線量は1\%2に軽減するが，結不に関する情㪕量を減ずる。 一般的管電圧撮影法で, 増感紙 LH-II, フィルム RXを
使用し，ルーチン検查の篎部腾胱部监純撮影を同時 1 回 撮影（半切版フィルムを使用）することにより，被曝線 量を $1 / 5$ に軽減しかつ画質む満足する写真を得た。

さらに腎部造影撮影に拈ける照射野に関する骖断上の 諸条件がゆるされれば，従来のルーチン検查時に比べ， 被曝線量を $1 / 10$ 亿軽減するとと屯可能であると考える。

3. 婦人科領域における直接性腺被曝線量の軽減につい $\tau$

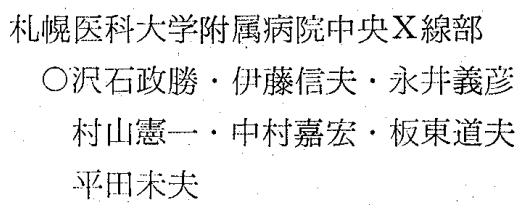

[目的]

被曝線量軽減については，学会等にて発表又は諭議さ れていますが，吾々はどこの施設でも簡単に実施出来る あのとして感光材料の組み合せにより，被曝線悬軽減を こころみた。

[夹験方法]

1 . 各增感紙,フィルムの組み合せによる濃度及び鮮 鋭度波形の比較.

2. 管電压及び距離の変化による被曝線量の比僌.

3. 透視時に打ける被懪線量の比較.

4. 連続撮影 AOT に打りる被曝線量の比較.

5.腰椎，股関節撮影に打ける被曝線量の比䡆。 [結果]

1. 彷来の FS での被曝量を $100 \%$ とした場合，LTII $\mathrm{KX}, \mathrm{Y}$ の組合せのもので40\%軽減出来た. 又 LH. II とRXS，QSの組み合せでは60\%の軽減が出来た。

2. 管電压の変化では $15 \sim 40 \%$ 軽減出来た。距離の変 化では15〜30\%軽減出来た。

3.オーバチューブではアンダチューブに比較し $40 \%$ 軽減出来た，透視時間では 1 分増す班に20\%の增加が解 った.

4. 連続撮影 AOT では東装 LMに比較し東芝 LU で は50\%の軽娍が出来た。摄影枚数では 1 枚増す㮩に $10 \%$ の增加が解った。

5. FS K KX，Yの組み合せに比し LH- I そ RXS, QS では $60 \%$ 軽減出来た。

[洘察]

性腺直接部位の被曝線量軽減では，管電圧は高電圧带 を用い感光材料では蘚鋭度は若干落ちても高感度のもの を使用すべきである，乙れは実験の結果，LH-IIでも十 分彰断洒值の得られる軎が解った. 又, 撮影の目的によ ってはもっと高感度のものを使用しても良いのではない か，そうする事により，一篔の軽減が出来る，透視時間 